\section{удк 378.14.015.62+331.522}

JEL classification: J21, J24, J62, M51, M53

\section{Наталія АБЛЯЗОВА}

кандидат економічних наук, кафедра менеджменту та адміністрування, Східноєвропейський університет імені Рауфа Аблязова, Україна

https://orcid.org/0000-0002-2367-9349

(C) Наталія Аблязова, 2020

Отримано: 20.11.2020 p.

Прорецензовано: 03.12.2020 p

Рекомендовано до друку: 16.12.2020 р.

Опубліковано: 16.12.2020 p.

\section{(i) (9)}

Ця стаття розповсюджується на умовах ліцензії Creative Commons AttributionNonCommercial 4. 0, яка дозволяє необмежене повторне використання, розповсюдження та відтворення на будь-якому носії, за умови правильного цитування оригінальної роботи.
Наталія Аблязова (Україна)

\section{СУЧАСНI МЕХАНІЗМИ ЗБАЛАНСУВАННЯ ВИЩОЇ ОСВІТИ ТА РИНКУ ПРАЦІ}

\begin{abstract}
АНОТАЦІя
Вступ. У статті досліджено сучасний стан вищої освіти, визначено проблематику незбалансованості розвитку освітніх послуг та попиту на ринку праці.

Мета дослідження - визначити відповідність напрямів підготовки фахівців, які пропонують вищі навчальні заклади, до структури економіки та потреб на ринку праці, оцінити рівень працевлаштування випускників вищих навчальних закладів.

Методи: методи порівняльного, статистичного, графічного аналізу даних. Під час дослідження було визначено, що структура випуску фахівців у системі вищої освіти не відповідає потребами економіки, у силу низки факторів, а обрання професій, здебільшого, визначається престижем та популярністю. Це призводить до дисбалансу на ринку праці та неефективному витрачанні державних та приватних коштів на вищу освіту.

Результати. У ході дослідження автором узагальнено наявні методичні підходи оцінки збалансованості кількості випускників вищих навчальних закладів та потреб ринку праці й економіки. У статті обґрунтовано необхідність розробки ефективних управлінських рішень у системі підготовки кадрів, спрямованих на їі збалансований розвиток та досягнення балансу економічних інтересів усіх суб'єктів, система вищої освіти має бути зосереджена на створенні ефективних інструментів прогнозування перспективних напрямків ії розвитку з урахуванням потреб ринку праці та економіки.
\end{abstract}

Аблязова Н. Р. Сучасні механізми збалансування вищої освіти та ринку праці. Економічний аналіз. 2020. Том 30. № 4. С. 15-22.

DOI: https://doi.org/10.35774/econa2020.04.015

Ключові слова: ринок праці; освіта; заклади вищої освіти; безробіття; збалансування; безробіття; попит та пропозиція; кваліфіковані фахівці. 
UDC 378.14.015.62+331.522

JEL classification: J21, J24, J62, M51, M53

\section{Nataliia ABLIAZOVA}

$P h D$ in Economics,

Associate Professor,

Department of Management and Administration, Rauf Ablyazov University East European, Ukraine https://orcid.org/0000-0002-2367-9349

(C) Nataliia Abliazova, 2020

Received: 20.11.2020

Revised: 03.12.2020

Accepted: 16.12.2020

Online publication date: 16.12 .2020

\section{cc) (1) 8}

This is an Open Access article, distributed unde the terms of the Creative Commons AttributionNonCommercial 4. 0 license, which permits unrestricted re-use, distribution, and reproduction in any medium, provided the original work is properly cited.
Nataliia Abliazova (Ukraine)

\section{MODERN MECHANISMS OF BALANCING OF HIGHER EDUCATION AND THE LABOR MARKET}

\begin{abstract}
Introduction. Article analyzes the higher education current state discusses problems and imbalances in its development and labor market demand.

The purpose of the study is to determine the relevance of the areas of training offered by the higher education institutions to the economy structure and the needs for specialists in the labor market, to assess the degree of employment of graduates of higher educational institutions.

Methods: methods of comparative, statistical, graphical analysis of the data. The study determined that the structure of specialists graduation in higher education systems, due to the influence of many factors, is often determined not by the needs of economic, but by the demand of the population in the field of education as well as the preferences and ideas of the applicants.

Results. This leads to an imbalance on the labor markets and inefficiency in spending public and private funds on higher education. In the course of the study, methodological approaches to assessing the balance between the number of graduates of higher educational institutions and the needs of the labor and economic markets are presented. The article substantiates the need to develop of coordinated management decisions in the personnel training system aimed at its balanced development and achieving a balance of economic interests of all actors should be focused on creating effective foresight tools for forecasting the promising directions for the education system development and taking into account the needs labor market and economy.
\end{abstract}

Abliazova, N. (2020). Modern Mechanisms of Balancing of Higher Education and the Labor Market. Economic analysis, 30 (4), 15-22.

DOI: https://doi.org/10.35774/econa2020.04.015

Keywords: labor market; education; higher education institutions; unemployment; balancing; unemployment; supply and demand; qualified specialists. 


\section{Вступ}

Суспільні трансформації та реформи в усіх галузях економіки, потребують переосмислення місця та ролі вищої освіти, підготовки кваліфікованих кадрів у сучасних реаліях. Наразі, в умовах пандемії та карантинних обмежень, ринок праці України, як і всього світу, визначив нові вимоги та критерії підбору персоналу для бізнесу. Так, поряд із наявністю вищої освіти до претендентів висуваються нові вимоги: мобільність, технічна підготовленість, здатність адаптування до нових умов праці тощо.

Отже, ураховуючи й так доволі високий рівень безробіття в Україні, нові вимоги ринку змушують роботодавців віддавати переваги досвідченим та «мобільним» фахівцям, залишаючи особам із вищою освітою менш затребувані робочі місця. Відтак, постає одвічне питання щодо доцільності функціонування значної кількості навчальних закладів та підготовки фахівців окремих професій, якими вже перенасичений ринок праці.

Проте, освіта й надалі залишається визначальною складовою, яка забезпечує: функціонування ринку праці, сприяє підвищенню його ефективності та мобільності, забезпечує соціальні гарантії та відповідний рівень життя. А розв'язання проблем ефективного планування потреби в кадровому забезпеченні галузей економіки сприяє стабільному соціальноекономічному стану держави.

Ураховуючи, що підготовка кадрів та насичення ринку праці залишаються актуальними завжди, дослідженню даного питання присвячено значну кількість праць науковців та практиків, таких як: В. Андрущенко, В. Антонюк, Д. Богиня, Л. Бражник, О. Грішнова, Л. Дробиш, Т. Заяць, І. Кириченко, О. Кочемировська, Е. Лібанова, Є. Ніколаєва, М. Семикіна, Л. Шевченко, О.Чумак та ін. Проте, не зважаючи на вагомі результати досліджень та отримані висновки й рекомендації, в Україні, і надалі, дискусійним залишається питання щодо збалансування підготовки фахівців закладами вищої освіти та насиченням ринку праці.

Водночас, найважливішою проблемою України $\epsilon$ незбалансованість розвитку вищої освіти та ринку праці, що обумовлює, з одного боку, надлишок на ринку праці фахівців певних напрямів підготовки, а з іншого - дефіцит висококваліфікованих кадрів за окремими спеціальностями [1]. Л.Дробиш та І. Кириченко неодноразово, у своїх дослідженнях, наголошували на порушення диспропорції між розвитком ринку освітніх послуг і ринку праці; $€$. Ніколаєва акцентувала увагу на проблемах визначення обсягів державного замовлення на підготовку фахівців різних спеціальностей без оцінки реальної потреби в них української економіки [2]; Л. Шевченком указано на відсутність комплексного підходу до прогнозування потреб у кваліфікованих спеціалістах 3 урахуванням структури національної економіки [3]. Відсутність статистичної інформації реального співвідношення попиту й пропозиції кадрів на ринку праці України констатувала О. Кочемировська [4].

Відтак, ураховуючи результати досліджень, сучасний стан ринку праці, рівень безробіття та кількість випускників вищих навчальних закладів, варто зазначити, що й до тепер відсутня достовірна оцінка рівня збалансованості обсягів та напрямів підготовки фахівців відповідно до потреб ринку праці. Також, і до тепер, відсутній ефективний механізм планування державного замовлення на підготовку окремих категорій фахівців тощо.

\section{Мета статті}

Метою статті $€$ обґрунтування підходів щодо оцінки збалансування підготовки фахівців закладами вищої освіти відповідно до потреб ринку праці. У процесі дослідження буде здійснено аналіз ринку безробіття та стан підготовки фахівців закладами вищої освіти.

\section{Виклад основного матеріалу дослідження}

Сьогодні, як в Україні, так і всьому світі, існує проблема щодо диспропорцій у чисельності зайнятих і безробітних осіб (з урахуванням їхнього рівня освіти).

Хоча, саме рівень освіти $€$ визначальним показником, для більшості країн світу, який впливає на працевлаштування випускників закладів вищої освіти та кваліфікованих кадрів на ринку праці. Проте, нині існує проблема наявності значної кількості випускників, які незатребувані на рику праці. Така ситуація, на жаль, спостерігається кожного року і тенденція продовжує зростати, не зважаючи на скорочення кількості навчальних закладів та випускників (рис. 1, табл. 1).

Отже, за даними Державної служби статистики, за період дослідження, кількість закладів освіти скоротилась майже на 200 одиниць. Так, заклади вищої освіти, станом на початок 2019/2020 н. р. налічували 281 од, в яких, у середньому, навчалось 1266121 студента, зокрема, 250,1 тис. осіб які вступили на навчання. Загальне скорочення проти 2010 р. становило 35,6\% [5]. Скорочення відбулось з різних причин - недотримання ліцензійних вимог, самостійне рішення про закриття, заклади освіти які залишились на території Донбасу та АР Крим. Відповідно було відмічено й скорочення осіб, які вступили та закінчили заклади освіти, майже вдвічі. Серед основних причин зменшення кількості осіб, що вступають до вишів присутній демографічний аспект та значний відтік абітурієнтів за кордон. 


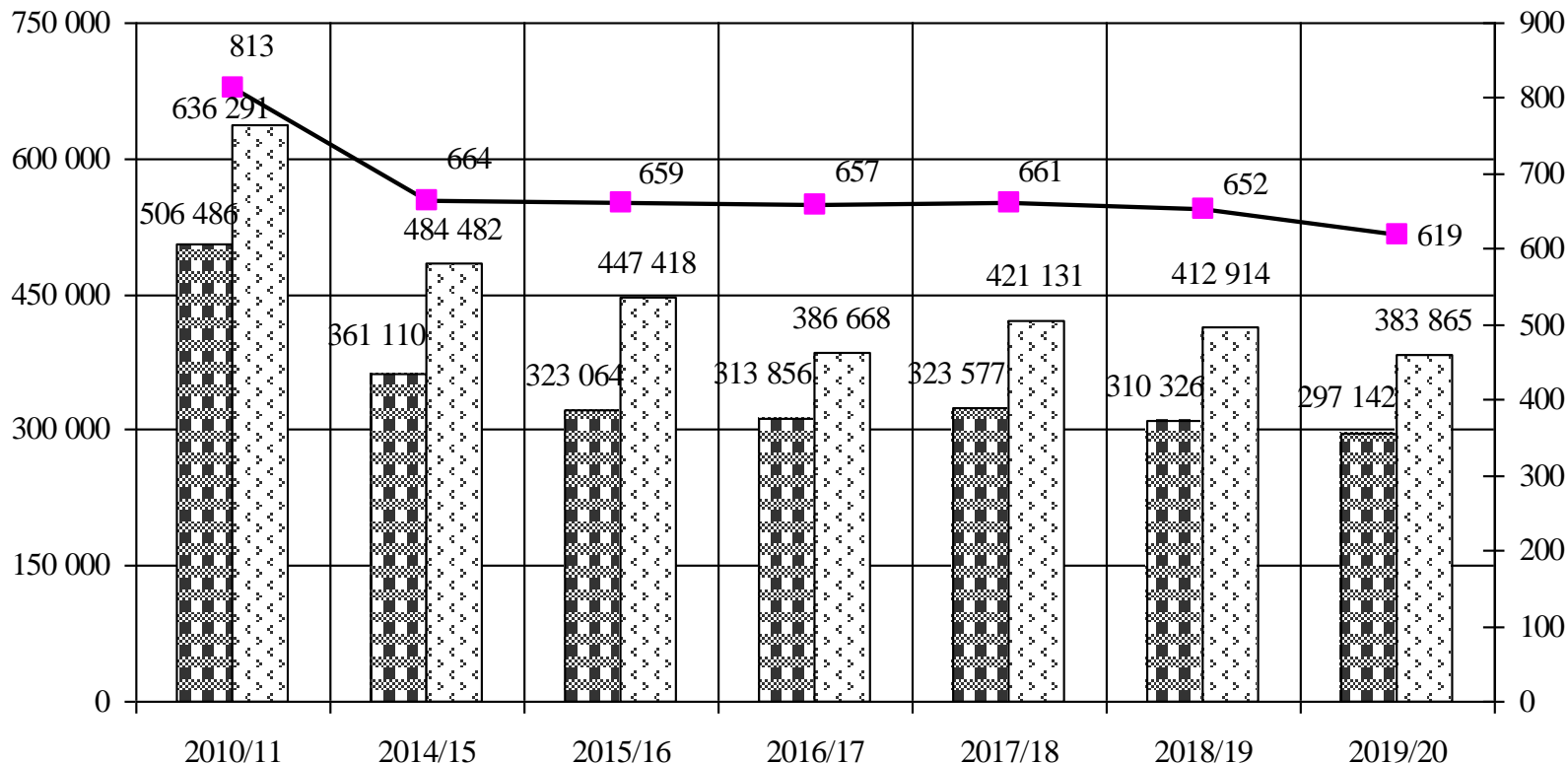

Кількість осіб, прийнятих на навчання, осіб '? Кількість осіб, випущених із ЗВО, осіб - - Кількість закладів, одиниць

Рис. 1. Динаміка навчальних закладів та студентів за 2010-2020 н. р.

Джерело: побудовано автором за даними Державної служби статистики України [5].

Ураховуючи динаміку скорочення чисельності населення України (станом на 01.01.2016 р. 42590,0 тис. осіб, станом на 01.01.2020 р. - 41732,0 тис. осіб), що супроводжується міграцією,

Таблиця 1. Рівень безробіття в Україні за 2010-2020 рр.

\begin{tabular}{|c|c|c|c|}
\hline Рік & $\begin{array}{c}\text { Безробітне населення } \\
\text { у віці 15-70 років, } \\
\text { тис. осіб }\end{array}$ & $\begin{array}{c}\text { у т. ч. непрацевлаштовані після } \\
\text { закінчення закладів освіти }\end{array}$ & $\begin{array}{c}\text { Частка безробітних випускників у } \\
\text { загальній кількості безробітних, \% }\end{array}$ \\
\hline 2010 & 1713,9 & 15,5 & 0,90 \\
\hline 2011 & 1661,9 & 18,1 & 1,09 \\
\hline 2012 & 1589,8 & 16,9 & 1,06 \\
\hline 2013 & 1510,4 & 16,8 & 0,90 \\
\hline 2014 & 1847,6 & 16,7 & 0,99 \\
\hline 2015 & 1654,7 & 16,4 & 0,93 \\
\hline 2016 & 1678,2 & 15,6 & 0,62 \\
\hline 2017 & 1698,0 & 12,2 & 0,63 \\
\hline 2018 & 1578,6 & 9,8 & \\
\hline 2019 & 1487,7 & 9,4 & \\
\hline
\end{tabular}

Джерело: побудовано автором за даними Державної служби статистики України [5].

Загальна динаміка, наведена в табл. 1, $\epsilon$ позитивною, адже за період дослідження частка безробітних, які не влаштувались на роботу після закінчення закладів освіти скорочується. Проте, існує інше питання, а саме, працевлаштування за профілем. Як показує практика значна кількість випускників влаштовуються на вільні місця, які здебільшого не відповідають отриманій кваліфікації. Причин даної ситуації багато, це - старінням нації та скороченням народжуваності, рівень безробіття, за офіційними даними, також скоротився (табл. 1). непомірковане обрання майбутньої професії, виходячи з престижу; вступ на місця державного замовлення (головне - безкоштовна вища освіта) тощо. Але найголовнішою причиною такого стану $\epsilon$ значна кількість закладів освіти, які готують фахівців які не відповідають сьогоденним потребам ринку, а за наявним ліцензованим обсягом.

Нажаль, система вищої України, у своїй діяльності орієнтується на ринок освітніх послуг, 
запит населення щодо освітніх послуг без урахування вимог ринку праці. Спільними для українських ринку освіти та ринку праці $\epsilon$ відсутність аналізу і прогнозу про кількість та кваліфікацію необхідних економіці працівників, відсутність гнучкої системи визначення кваліфікації, а також слабкий зв'язок ВНЗ із потенційними роботодавцями для своїх випускників [6].

Незбалансованість ринку праці та ринку освітніх послуг має такі наслідки: збільшується частка випускників вищих навчальних закладів, які працевлаштовуються не за отриманою спеціальністю, що знижує цінність здобутої освіти, а при тривалій роботі не за спеціальністю - втрату професійних знань і відповідної кваліфікації; для роботодавців виникає необхідність організації додаткової підготовки та перепідготовки фахівців, які не мають необхідної кваліфікації, що вимагає додаткових фінансових і матеріальних витрат, організаційних зусиль, що відволікає кошти та інші ресурси від безпосередньої виробничої діяльності; неможливість задовольнити потреби підприємств, організацій у фахівцях певних професій i спеціальностей призводить до зниження продуктивності праці, обсягів та якості товарів і послуг, погіршення можливостей інноваційного розвитку, зниження конкурентоспроможності підприємств і країни в цілому [1].

Наразі ці питання, частково намагаються врегулювати шляхом проведення реформ у Вищій школі, проте це здебільшого стосується державних закладів освіти.

Відтак, України стикнулась 3 проблемою відсутності актуальної статистичної бази для прогнозування кадрових потреб у професійному/кваліфікаційному розрізах; необгрунтованістю результатів стратегічного планування видів економічної діяльності та його працересурсного сегменту тощо. Також відсутній зв'язок спеціальностей, освітніх стандартів 3 професійними кваліфікаціями тощо [7].

Сучасна система освіти та підготовки кадрів повинна відображати конкретні оперативні і, безумовно, перспективні потреби розвитку країни. Проте, організація взаємодії ринку праці й освітніх закладів процес не простий і потребує не лише проведення певних реформ, а й адаптування та впровадження провідних світових практик. Так, наприклад, у Великій Британії щороку публікується «Заява про вимоги до кваліфікацій вищої освіти». Документ розробляється спільно всіма учасниками суспільного виробництва та $\epsilon$ орієнтиром для закладів освіти щодо формування стратегічних векторів навчання.

Наразі, у світі, існує значна кількість ефективних систем прогнозування кадрових потреб. Так, Європейська модель побудована на чіткій взаємодії окремих інформаційно-стандартних систем, а саме: Європейської класифікації умінь/компетентностей, кваліфікацій та професій [8], Міжнародної стандартної класифікації занять (ISCO-08); Міжнародної стандартної класифікації освіти (ISCED-2011) [9] тощо. Поряд із тим, існує й велика різноманітність методологічних підходів щодо аналізу та прогнозування стану ринку праці, визначення потреб у кадрах та/чи кваліфікаціях, оцінювання рівня безробіття [10]. Основні методики представлено в таблиці 2.

Наведені методики, зазвичай не використовуються окремо одна від одної. Здебільшого відповідні аналітичні центри поєднують різні методи 3 метою отримання оптимальних показників щодо стану ринку праці та його реальної потреби.

Державна служба статистики України, у дослідженнях щодо збалансування попиту та пропозиції на ринку праці, з метою виявлення впливу надлишкової (недостатньої) підготовки кадрів закладами вищої освіти в розрізі професій та спеціальностей, та при прогнозуванні кадрових потреб використовує криву Беверіджа. Саме цей метод застосовується, як практичний інструмент для узагальнення вхідних і вихідних часових характеристик безробіття, вакансій тощо. Даний метод поєднують із методом співвідношення чисельності безробітних і зайнятих, що дозволяє визначити потребу в кадрах.

Використовуючи зазначені методики, упродовж останніх п'яти років різні Науково-дослідні установи здійснювали моделювання ринку праці, попиту на певні професії та намагались спрогнозувати оптимальне співвідношення випускників певних вишів та спеціальностей.

Так, на основі наведених методик було здійснено оцінку взаємодії системи вищої освіти $з$ економікою країни та визначено, що найбільш затребувані напрями підготовки студентів, які необхідні державі - це математика, фізика, будівництво, інформаційні технології, електроенергетика, програмна інженерія, обчислювальна техніка тощо. У той час, як психологами, журналістами, юристами, економістами ринок праці перенасичений. Так, 2020 н. р. було випущено 39654 студенти за напрямом - соціальні науки, бізнес і право (при потребі на ринку праці 12540 осіб), а за напрямами природничі науки та інженерія - 27467 осіб (за потреби - 61231 особи) [5].

Відтак, актуальним та таким, що потребує негайного врегулювання залишається питання збалансування підготовки фахівців закладами вищої освіти відповідно до потреб ринку. Саме за допомогою статистичних даних та наведених методик, фахівцями може бути розрахований 
www.econa.org.ua

коефіцієнт збалансованості потреби та пропозиції фахівців на офіційному ринку праці, з урахуванням чисельності випускників певних спеціальності упродовж п'яти років, середньої чисельності безробітних та середньої чисельності вакансій. На основі даних показників розраховують й прогноз потреби у випускниках на повному ринку праці.

Таблиця 2. Методологічних підходів щодо визначення невідповідності попиту на ринку праці та пропозиції випускників закладів вищої освіти

\begin{tabular}{|c|c|}
\hline Метод & Характеристика \\
\hline $\begin{array}{l}\text { Метод коефіцієнта варіації } \\
\text { [11] }\end{array}$ & $\begin{array}{l}\text { дозволяє порівняти ступінь варіації для декількох серій даних, навіть якщо середні } \\
\text { значення суттєво відрізняються один від одного. Варіація розраховується як } \\
\text { відношення стандартного відхилення до середнього значення і іноді множитися на } \\
100 \text { для вираження у відсотках }\end{array}$ \\
\hline $\begin{array}{l}\text { чня } \\
\text { чисельності } \\
\text { йнятих [12] }\end{array}$ & $\begin{array}{l}\text { порівнює чисельності безробітних, які мають певний рівень освіти, з відповідною } \\
\text { чисельністю працівників цього ж рівня освіти (визначає надлишковість або } \\
\text { дефіцитність певного рівня освіти на ринку) }\end{array}$ \\
\hline осного рівня & $\begin{array}{l}\text { використовує характеристики тільки для однієї групи, дозволяє спрогнозувати } \\
\text { довгострокове безробіття за певними факторами }\end{array}$ \\
\hline Крив & $\begin{array}{l}\text { відображає залежність між рівнем безробіття і часткою вакансій у декількох } \\
\text { фіксованих часових точках для певного комплексу заходів щодо збалансування } \\
\text { попиту і пропозиції робочої сили на ринку праці }\end{array}$ \\
\hline $\begin{array}{l}\text { Систематичне оцінювання } \\
\text { виконання трудової функції } \\
\text { [15] }\end{array}$ & \begin{tabular}{|l} 
рівень необхідних професійних кваліфікацій визначається за допомогою \\
формування відповідних стандартів та критеріїв
\end{tabular} \\
\hline $\begin{array}{l}\text { Метод самооцінки } \\
\text { працівників [16] }\end{array}$ & $\begin{array}{l}\text { ґрунтується на опитуванні зайнятих стосовно того, як вони використовують свої } \\
\text { професійні та освітні компетентності у професійній та трудовій діяльності }\end{array}$ \\
\hline $\begin{array}{l}\text { Метод визначення } \\
\text { невідповідності за } \\
\text { професіями [17] }\end{array}$ & $\begin{array}{l}\text { метод заснований на розрахунку відношення чисельності людей з певним рівнем } \\
\text { освіти за Міжнародною стандартною класифікацією освіти, які працюють за } \\
\text { професіями, з невідповідним рівнем кваліфікації, який визначається Міжнародною } \\
\text { стандартною класифікацією знань }\end{array}$ \\
\hline $\begin{array}{l}\text { Мет } \\
\text { окуп }\end{array}$ & $\begin{array}{l}\text { розрахунок повернення коштів інвестованих в освіту (грошова вартість яку } \\
\text { пропонує ринок праці для різних рівнів освіти) }\end{array}$ \\
\hline $\begin{array}{l}\text { Метод зіставлення } \\
\text { відносних рівнів зарплат } 3 \\
\text { освітніми рівнями [18] }\end{array}$ & $\begin{array}{l}\text { порівнює заробітну плату для кожного рівня освіти з плином часу відносно } \\
\text { мінімального розміру оплати праці }\end{array}$ \\
\hline
\end{tabular}

На основі отриманих розрахунків держава може формувати державне замовлення на підготовку фахівців та регулювати ліцензійні обсяги підготовки фахівців певної галузі.

\section{Висновки та перспективи подальших розвідок}

Ефективність вищої освіти, компетентність випускників та їхня практична підготовка, залишаються актуальною темою для подальших досліджень, не лише для України, а й усього світу. Адже, якість підготовленого фахівця, його інтелектуальний потенціал прямо впливають на розвиток економіки загалом, та ї̈ нових галузей. Відтак, сучасна система освіти зобов'язана миттєво реагувати на зміни попиту на ринку праці, формуючи нові компетенції, знання. Система підготовки фахівців зобов'язана максимально відповідати потребам ринку праці, як у кількісному, так і якісному, вимірах.

Ураховуючи актуальність досліджуваної проблематики, ми вважаємо, що на рівні закладів освіти та держави, і надалі повинна відбуватись взаємодія щодо збалансування попиту й пропозиції випускників закладів освіти. Також, необхідно впроваджувати нові технології в освітній процес, які дозволять швидко адаптуватись до змін на ринку праці та підготовки фахівців.

\section{СПИСОК ВИКОРИСТАНИХ ДЖЕРЕЛ}

1. Антонюк В. П. Вища освіта України у системі відносин ринку праці. Економічний вісник Донбасу 2015. № 2(40). С.132-137. 
2. Чумак O. B. Механізм регулювання взаємодії вищо освіти з ринком праці. Народна освіта. 2017. Випуск №3(33). URL: https://www.narodnaosvita.kiev.ua /?page_id=5081.

3. Шевченко Л. Дисбаланс професійної освіти і ринку праці: сутність, причини, шляхи подолання. URL http://www.rusnauka.com/ 5_PNW_2010/Economics/58093.do c.htm.

4. Кочемировська О. О. Щодо посилення відповідальності Міністерства економічного розвитку і торгівлі України за формування державного замовлення на підготовку кадрів для економіки. Київ: Національний інститут стратегічних досліджень. 2014. URL:

http://www.niss.gov.ua/articles/14 $84 /$

5. Державна служба статистики України. URL: http://www.ukrstat.gov.ua.

6. Кириченко І. Битва за професіоналізм. Дзеркало тижня. 2012. № 33. URL http://dt.ua/SOCIETY/bitva_za_prof esionalizm-109104.html.
7. Методологічні підходи до оцінки кадрових потреб у фахівцях із вищою освітою зі спеціальностей. За ред. С. В. Мельник. Київ: ДНУ «Інститут освітньої аналітики». 2020. URL: https://iea.gov.ua/wpcontent/uploads/2020/06/2na_sajt_AZ_Melnik_SV_Metodolog_ pidh_otsinki_kadr_potr_fah_VOfinal.pdf.

8. Європейська класифікація умінь/компетентностей, кваліфікацій та професій (занять). Europenian Occupations, Skills / Competences, Qualications (ESCO). URL:

https://www.youtube.com/watch?t ime_continue $=2 \& v=H n R E E e t R 87 \mathrm{~s}$.

9. Міжнародна стандартна класифікація занять (ISCO-08). URL:

https://www.ilo.org/moscow/infor mation-

resources/publications/WCMS 306 604/lang--en/index.htm.

10. Міжнародна стандартна класифікація освіти (ISCED-2011). URL:

http://www.uis.unesco.org/Educati on/Documents/isced-2011-en.pdf.

11. Бахрушин В. Є. Методи аналізу даних: навч. посіб. Запоріжжя : Класичний приватний університет. 2011. URL: http://web.kpi.kharkov.ua/auts/wpcontent/uploads/sites/67/2017/02/ DAMAP_Ivashko_posobie2.pdf.

\section{REFERENCES}

1. Antonyuk, V. (2015). Higher education of Ukraine in the system of relations of the labor market. Donbass of Economic Bulletin. Retrieved from: http://www.evdjournal.org/download /2015/2(40)/pdf/18-Antonuk.pdf [in Ukrainian].

2. Chumak, O. (2017). The Regulation Mechanism of Interaction of Higher Education with Labour Market. Public education, 3(33). Retrieved from: https://www.narodnaosvita.ki ev.ua/?page_id $=5081$. Ukrainian].

3. Shevchenko, L. (2010). Imbalance of vocational education and the labor market: the essence, causes, ways to overcome. Retrieved from: http://www.rusnauka.com/ 5_PNW_2010/Economics/58093.do c.htm [in Ukrainian].

the Ministry of Economic Development and Trade of Ukraine for the formation of a state order for training for the economy. Kyiv: National Institute for Strategic Studies. Retrieved from: http://www.niss.gov.ua/articles/14 84/.[in Ukrainian].

5. State Statistics Service of Ukraine. Retrieved from: http://www.ukrstat.gov.ua/[in Ukrainian].

6. Kyirychenko, I. (2012) The Battle for Professionalism. Mirror of the week: 33. Retrieved from: http://dt.ua/SOCIETY/bitva_za_prof esionalizm-109104.html [in Ukrainian]

7. Melnyk, S. (2020). Methodological
12. Аналіз державної політики зайнятості. URL: https://parlament.org.ua/2005/08/ 16/employment-policy-researchukraine/.

13. Завіновська Г. Т. Економіка праці : навч. посіб. КНЕУ. Київ. 2003.

14. Підтримання темпу процесу децентралізації в Україні. Париж: OECP, $2018 . \quad$ URL: https://www.oecd.org/countries/uk raine/9789264301481-uk.htm

15. Довгань л. $€$. Технології управління людськими ресурсами: підручник. Київ: КП। ім. Ігоря Сікорського, 2018. 512 с.

16. Колот А. М., Цимбалюк С. О. Мотивація персоналу : підручник. Київ, 2012. 397 с.

17. Аналітичний звіт щодо професійно-кваліфікаційного прогнозування в Україні / Робочий проект для обговорення 9 листопада 2017 р. у м. Києві. URL: https://mon.gov.ua/storage/app/m edia/nrk/Analitychni-materialy/2analitichniy-zvit-shchodoprofesiyno-kvalifikatsiynogoprognozuvannya-v-ukraini.pdf.

18. Сисоєва С. О., Кристопчук Т. Є. Освітні системи країн Європейського Союзу: загальна характеристика : навч. посіб. Київський університет імені Бориса Грінченка. Рівне : Овід. 2012. 352 c.

8. Europenian Occupations, Skills Competences, Qualications (ESCO). Retrieved from: https://www.youtube.com/watch?t ime_continue $=2 \& v=$ HnREEetR87s . approach to the assessment of personnel needs for employees and their education. Kyiv: Institute of Educational Analytics. [in Ukrainian]
International Standard Classification of Occupations (ISCO). https://www.ilo.org/moscow/infor mationresources/publications/WCMS 306 604/lang--en/index.htm

10. UNESCO (United Nations Educational, Scientifi c, and Cultural Organization). 2011. International Standard Classifi cation of Education: ISCED 2011. Montreal: UNESCO Institute for Statistics. http://www.uis.unesco.org/Educat

11. Bakhrushin, V. (2011). The Methods of Data Analysis. [in Ukrainian].

12. Analysis of state employment policy. 16/employment-policy-researchukraine [in Ukrainian]. on/Documents/isced-2011-en.pdf.

https://parlament.org.ua/2005/08/ 
13. Zavinovska, G. (2003). Labor Economics. Kyiv: KNEU. [in Ukrainian].

14. Maintaining the Momentum of Decentralisation in Ukraine. (2018).

Paris : OECD Publishing. https://www.oecd.org/countries/uk raine/9789264301481-uk.htm. [in English].

15. Dovgan, L. (2018) Personnel management technologie s. Kyiv: KPI Imeni Igorya Sikorskogo. [in Ukrainian].
16. Kolot, A. M. and Tsymbaliuk, S. O. (2012). Staff motivation. KNEU, Kyiv, Ukraine. [in Ukrainian].

17. Analytical report on professional qualification forecasting in Ukraine.

(2017). Retrieved from: https://mon.gov.ua/storage/a $\mathrm{pp} / \mathrm{media} / \mathrm{nrk} /$ Analitychnimaterialy/2-analitichniy-zvitshchodo-profesiynokvalifikatsiynogo-prognozuvannyav-ukraini.pdf. [in Ukrainian].
18. Sysoeva, S. O., Kristopchuk, T. E. (2012). Educational systems of the countries of the European Union: general characteristics. Rivne: Ovid. [in Ukrainian]. 